\title{
Reflection of labour issues in bengali cinema in post colonial era
}

\author{
Apurba Chakraborty \\ Inspector of College, University of Gour Banga, Malda, West Bengal, India \\ *Corresponding Author: Apurba Chakraborty \\ Email: drapurbaic@gmail.com
}

\begin{abstract}
In true sense serious discussion on Bengali cinema and their effect in the civic society was not discussed in a wide range. Labour concepts and their class, community, culture have not come to focus in Bengali Cinema during post-colonial period. The cinema can be used as an instrument to help people get rid of obscurantism and also to guide them along the right path. It can help in removing ignorance from our society. Not only this, several much needed social reforms can be introduced and brought about with the help of the cinema (debate.org). It's a debatable that how literacy base cinema came to take gigantic plea on social matter. Literature is a wealth of the society that is very important role for knowing a society in every aspect. In Bengali literature labour related discussion had not come in wide range but the issues are reflected in some great Bengali cinemas such as Chinnamul (1950), Ajantrik (1958), Abhijaan (1962), Hansuli Banker Upakatha (1962), Sagina Mahato (1970), Dhanraj Tamang (1978), Heerak Rajar Deshe (1980), Padma Nadir Majhi (1993), Chokh (1982) etc.
\end{abstract}

Keywords: Bengali cinema, Marginal workers, Unorganised labour, Migration, Untouchability, Racism, Agriculture labour.

\section{Introduction}

Labour related focus on Bengali cinema is neither a new concept nor a wide ranges discussion on context of post colonial era. Nowadays a countable number of social scientist has been paying their attention on this matter in a new manner as well as Bengali cinema critics also trying to absorb their analytic discussion. Cinema is the mirror of a society and serious matter of the society had been bearing very importance message to the people. To discuss on this matter very good number Bengali cinema was released in several years. In the article named 'Influence and Importance of Cinema on the Lifestyle of Educated Youth: A study on University Students of Bangladesh' by Istiak Mahmood, Sociology Discipline, Khulna University published in IOSR Journal Of Humanities and Social Science, pointed out that "...Cinema is the most complex and powerful art form in the present world. It can help us to better understand our own lives, the lives of those around us and even how our society and culture operate. They can shed light on political and spiritual matters too and can provide catharsis and perspective and may open our eyes to new ways of thinking, feeling and pursuing our lives". Cinema had really played a key function in changing our society. Patriotic movies construct us keep in mind to love our nation. Comedic movies had treated many patients through laugh therapy. Adventure movies had specified us a sense of escapade to explore new possibilities. There are more! In our society there are many practices and traditions which are based on ignorance and which have withheld the progress of our society. Some social customs such as untouchability, caste system, dowry system and purdah system have done enormous harm to our society. The cinema can be used as an instrument to help people get rid of obscurantism and also to guide them along the right path. It can help in removing ignorance from our society. Not only this, several much needed social reforms can be introduced and brought about with the help of the cinema (debate.org). It's a debatable that how literacy base cinema came to take gigantic plea on social matter. Literature is a wealth of the society that is very important role for knowing a society in every aspect. In Bengali literature labour related discussion had not come in wide range but the issues are reflected in some great Bengali cinemas such as Chinnamul (1950), Ajantrik (1958), Abhijaan (1962), Hansuli Banker Upakatha (1962), Sagina Mahato (1970), Dhanraj Tamang (1978), Heerak Rajar Deshe (1980), Padma Nadir Majhi (1993), Chokh (1982) etc.

\section{Role of cinema in society with special reference to bengali cinemas}

Bengali cinema has been bearing a long term traditional view. Most of the cinema released for charming entertainments among the people. All though majority portion in the Bengali cinema focused on entertainment things along with sex and violence but a serious appeal has been come to time to time. Since post-colonial period there are many changes including shift from classical Indian mythology to modern era in Indian cinema.

\section{Storyline of cinemas}

Lakshmi Srinivas's in his "Another cinema, another audience" on International Conference on Broadcasting Media \& Film Industry (Scientific Tracks: J Mass Communicat Journalism.

DOI: $10.4172 / 2165-7912 . S 1.002$ ) had been specifically marked that Indian Cinema had advanced to take in hand the country's multi-culturalism and the severe multiplicity of its inhabitants. While the Bollywood culture is over and over again conflated with 'Indian' cinema, in reality, there are a few film industries and many remarkable cinemas in India. Heterogeneity shapes of cinemas together with participatory audiences and interactive public surroundings making it a distinctive culture of cinematic entertainment. How can we understand cinema in Bengal, its culture and institutions in the background of ongoing change? How can Bengali cinema tell understandings of the nature and significance of 
cinema more generally? These questions become significant for a comparative standpoint on cinema.

\section{Case study on some selected bengali cinemas}

Chinnamul (1950): The cinema was directed by Nemai Ghosh was concerning a group of agriculture labour from East Pakistan (now Bangladesh) who were forced to migrate to Calcutta because of the partition of Bengal in 1947.

There had been a number of events which eventually helped us to achieve freedom from the colonial British rule. In this regard the shocking turn of dealings during and in the aftermath of partition managed to invoke a feeling of shock for the enormous loss of lives and property. A few contemporary Bengali films depicted the partition though the issues related to refugee camps and the pain of displacement had not been explored that much. Chinnamul is one of the pioneer Bengali movies based on the theme of India's tragic partition which mentioned the tragic migration of people and their heartbreak along with millions of refugees the family has to face untold misery in big city. The film is based on a story of Swarnakamal Bhattacharya.

This was the first Indian film that dealt with the partition of India. The story revolved around a group of farmers from East Pakistan (now Bangladesh) who were forced to migrate to Calcutta because of the partition of Bengal in 1947.

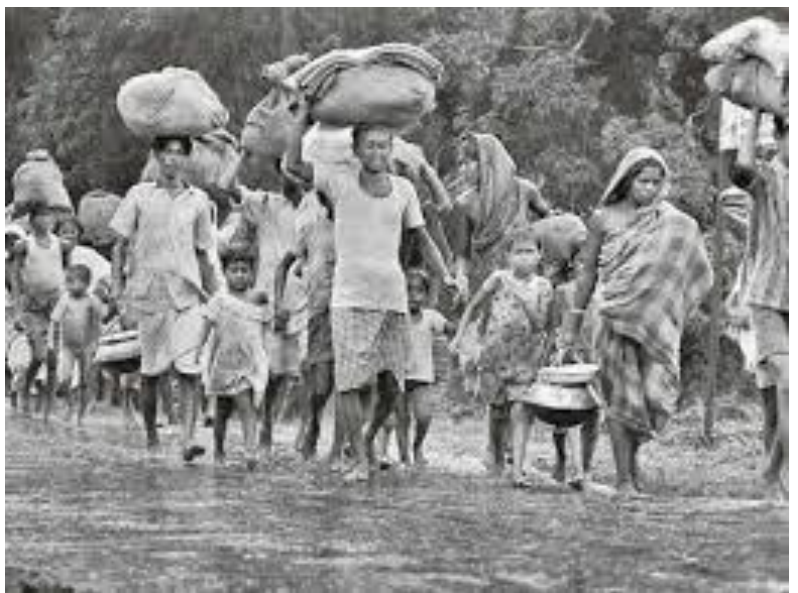

Scene from Chinnamul (1950)

Ajantrik (1958): This film was directed by Ritwik Ghatak. This is a complex movie which, shows how humans relate to each other.

Bimal is a taxi-driver in a small town. His taxi is his only companion and, although very battered, it is the apple of Bimal's eye. The film shows the love of taxi driver Bimal and his pathetic vehicle Jagaddal. We come across several situations with people looking to go here or there and Bimal and Jagaddal prove equal to the task. He often gets mocked for the poor state of his car and even gets called a madman. Yet, he never gives up on Jagaddal. In the end, Jagaddal's age finally manages to catch up and it is sold to a scrap merchant. Bimal is distraught and cries when he sees labourers taking his car apart.

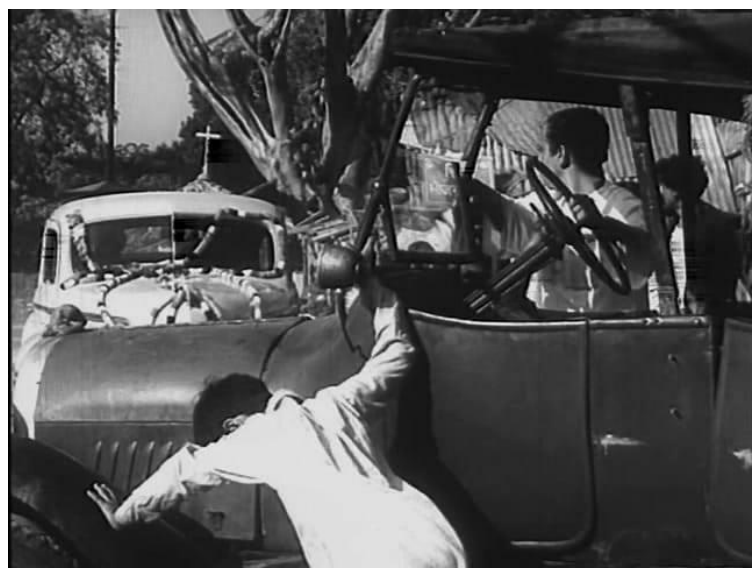

Scene from Ajantrik (1958)

Abhijaan (1962): This is directed by Satyajit Ray. This is a story of a taxi driver, a representative of unorganized lacour force, who attempts to introduce his cab service in rural Bengal against many odds. This movie implicitly states about the clash between unorganized labour force and the bureaucrat system.

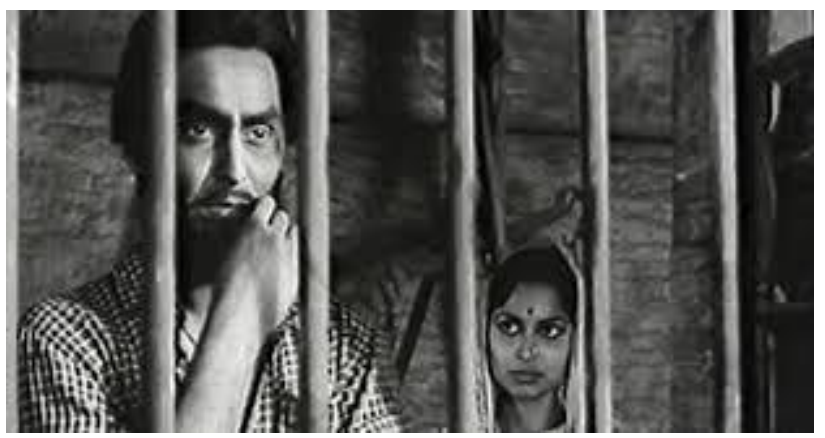

Scene from Abhijaan (1962)

Hansuli Banker Upakatha (1962): Hansuli Banker Upakatha (first published: 1951) is a novel by Tarashankar Bandopadhyay, set in 1941. The novel explores life in rural Bengal, the realities of the Zamindari system that was responsible for much of the social inequalities in Bengal, as well as the changes in social perceptions with time.

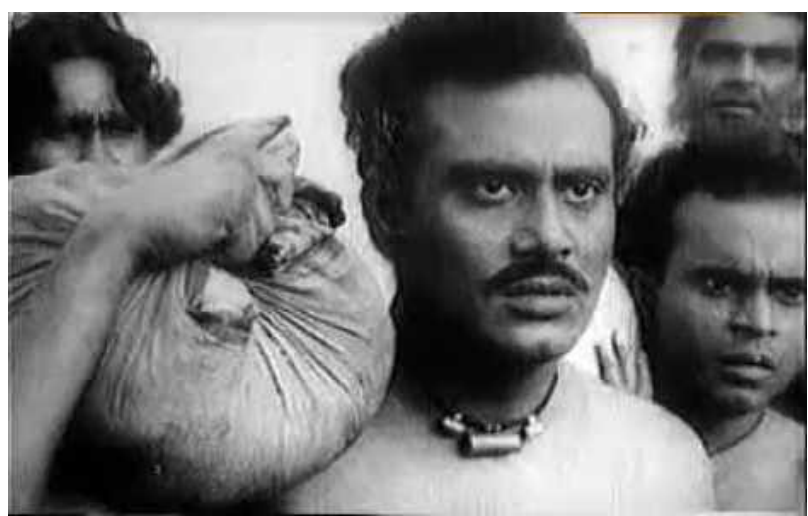

Scene from Hansuli Banker Upokatha 
Sagina Mahato (1970): Sagina Mahato, is one of the remarkable Bengali film in 1970, directed by Tapan Sinha with the major cast of Dilip Kumar, Saira Banu, Anil Chatterjee. This movie is about a factory laborer with an aggressive, honest and lovable character who first fought against the tyranny of the British bosses in the Tea gardens of North-Eastern India. The film was largely based on the life of Sagina Mahato. The story is inspired by real-life incidents with a touch of dramatization for the sake of commercial presentation. This Bengali classic was also remade in Hindi as 'Sagina' in 1974 (Times of India).

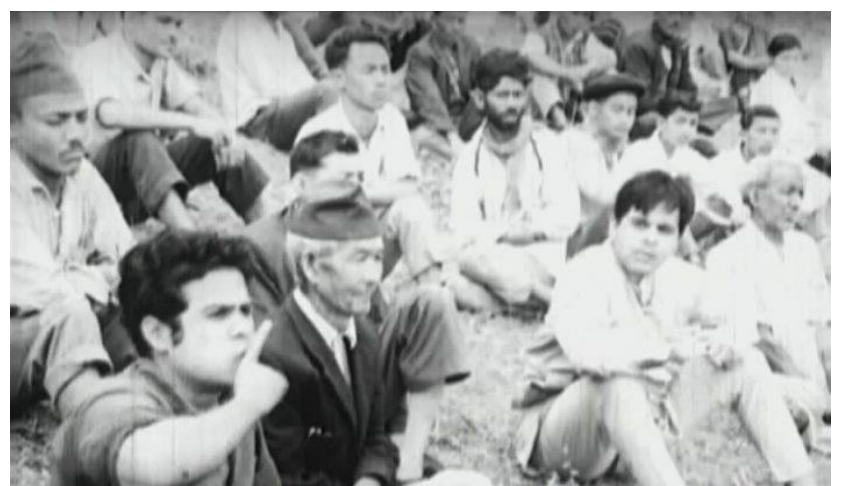

A scene from the cinema 'Sagina Mahato'; Source: rarefilm.net

Dhanraj Tamang (1978): Dhanraj Tamang, directed by Piyush Bose, is the story of a man who lived for others. However when it came to his life, he was unable to help himself and when he was able to, it was too late. Life had taken away everything he ever had. This cinema focuses on the life tea plantation labourers and their various socioeconomical problems as well as insecurity of women labourers in work place.

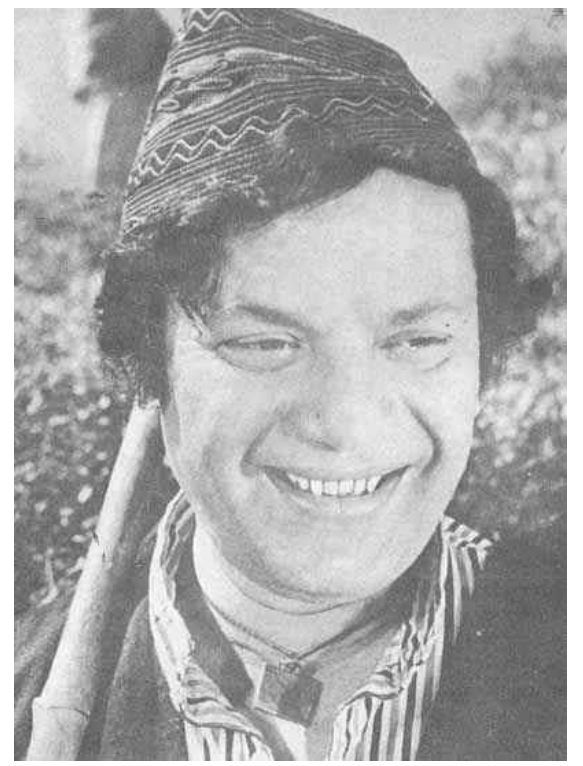

Scene from the cinema "Dhanraj Tamang";

Source:

http://www.geocities.ws/chotkab/Movie/Uttam1.html
Heerak Rajar Deshe (1980): Hirak Rajar Deshe is a story of a tyrant king, who owns a diamond mine, compels the working class to work hard and pay huge sum of tax. The story is based on the exploitation of poor farmers and diamond-miners which were symbol of marginal labour. They had been fighting day to day life for the meet up their basic needs but their whole hearted effort made the fortune of the king. Goopy and Bagha set out to correct the evils with the help of their skills offered by the king of the ghost. The absconded teacher, Udayan Pandit, was the leader of the peasants and labourers who fought against the antipeople activities by the King. He tried to organized the unorganized the workers of the diamond mines and the peasants. In this context it was clearly mentioned the theory of involvement of outside leadership on the organized movement of the unorganized peasant and labourers.

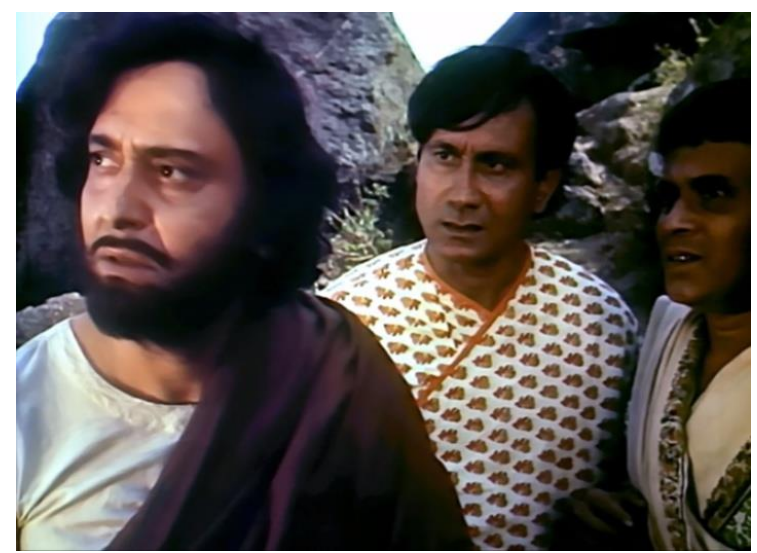

Scene from the cinema 'Heerak Rajar Deshe'; Source: http://livingtips4u.tk

Padma Nadir Majhi (1993): Hossain, a Bengali Muslim trader who wanted to establish a little Utopia with an idealistic vision on an island in the Padma delta. He doesn't care if the people who populate it are Hindu or Muslim. In this cinema fisherman lifehood and various critical problems as well as racism had been depicted in several times. Most of the characters were belonging to the unorganized poor class. Their needs and day to day problems had not compromised and fought against the mal-practice which was symbolic of the fighting of the working class against the odds.

It was apparent that Hossian Miya had flourished business there and purchased a huge boat for expanding business. He did not care if the people who populate it were Hindu or Muslim. In 1947, just before the partition of India, a Hindu fisherman Kuber accepted an offer by Hossain to ferry some of the community's cargo from the island. Throughout the story a concept of communal harmony among the working class mentality had developed irrespective of cast and race. 


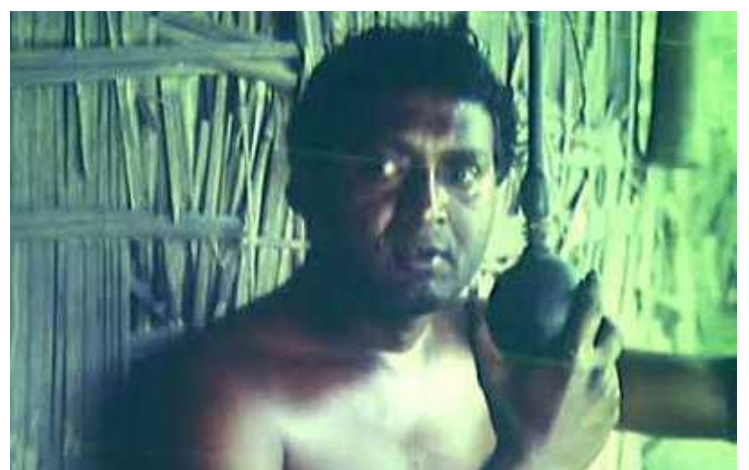

Scene from Padma Nadir Majhi

Chokh (1982): This was a Bengali film of the year of 1982 directed by Utpalendu Chakrabarty, starred with Om Puri, Anil Chatterjee, Shyamanand Jalan and Sreela Majumdar in lead roles. The main theme of the film was set in 1975 stating about the oppression and exploitation of Jute mill workers in Kolkata.

In the story of this cinema, Jadunath was a labour union leader of the Jethia Jute Mill in Kolkata. Jadunath was convicted in the murder case of the owner Jethia's brother and another worker. He had been given death sentence for the crime even though actually he never committed them. Before dying, he pledged his eyes for donation. However, when the mill owner found about this, he tried to trick the medical system to get both the eyes for his blind son. Meanwhile, the doctor discovered that the donation papers provided by the Jethia were fakes. Soon the mill workers got united behind the widow of Jadunath and hold protest rally against the injustice.

This cruelly honest cinema confessed the fact that filmmaking was also a socially informative. Interestingly this cinema was made on the subject of Eye Transplant unified with the malicious abuse of mill workers by their opportunist employers. The film exposed the caste system in the society and also revealed the hidden dreadful side of the capitalist structure, where the poor is not allowed any kind of freedom even after his final liberation after Death. With an exceptional theme, this cinema demonstrated an established truth that eyes are the reflection of a man's inner personality and a rebellion can still be seen in the donated eyes of a rebellious leader even when they are later given to an entirely different person as per his last wish.

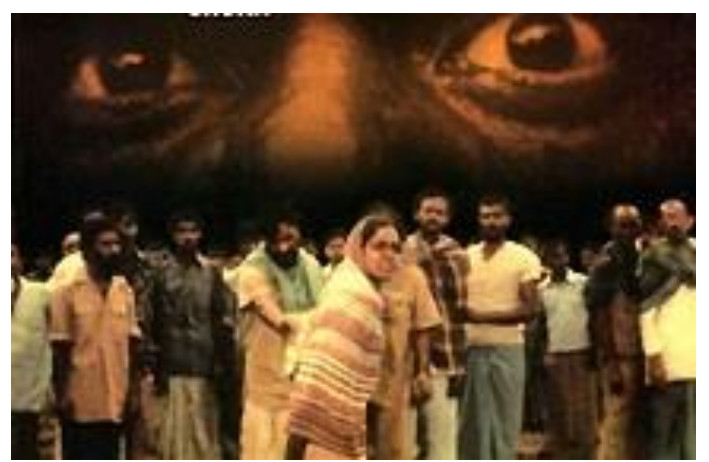

Scene from the cinema Chokh (1982)

\section{Conclusion}

It is difficult to say that Bengali movies and their storylines was covered by the theme of purely traditional urban culture. So most of the serious Bengali movies tried to focus almost all every aspects of the the then burning issues of the society. Chinnamul was made on the story of various struggles of the migrant people during partition of Bengal. This was the first Indian film that dealt with the partition of India. The story revolved around a group of farmers from East Pakistan (now Bangladesh) who were forced to migrate to Calcutta because of the partition of Bengal in 1947. Ajantrik was a complex movie which, showed how humans relate to each other. Abhijaan implicitly stated about the clash between unorganized labour force and the bureaucrat system. Hansuli Banker Upakatha explored life in rural Bengal and the Zamindari system that was responsible for much of the social inequalities in Bengal, as well as the changes in social perceptions with time. Sagina Mahato was about a tea factory laborer who first fought against the tyranny of the British bosses in the Tea gardens of North-Eastern India. Dhanraj Tamang focused on the life tea plantation labourers and their various socio-economical problems as well as the insecurity of women labourers in work place. Heerak Rajar Deshe mentioned the theory of involvement of outside leadership on the organized movement of the unorganized peasant and labourers. Padma Nadir Majhi stated the needs and day to day problems of unorganised labourers which was not compromised and the fight of the labourers against the socio-economic malpractice which was symbolic of the fighting of the working class against the odds. Chokh stated about the oppression and exploitation of the Jute mill workers in Kolkata and how they organized by an incident. After careful consideration of all the related Bengali movies which paid attention to the questions of various labour related issues, it seems that the detailed overall problems and issues of the unorganized labour are not properly reflected in the Bengali cinemas. It can also be observed that this particular issue has been reflected in a very few numbers of Bengali cinemas in terms of volume of cinema produced in the last decades.

\section{Source of funding}

None.

\section{Conflict of interest}

None.

\section{References}

1. Allen, R. and Smith, M. (eds.) (1999). Film Theory and Philosophy. Oxford: Oxford University Press.

2. Branigan, E. (1992). Narrative Comprehension and Film. London: Routledge.

3. Bruner, J. Making Stories. London: Harvard University Press, 2002.

4. Kermode, F. The Sense of Ending. London: OUP 1966.

5. Zipes, J. Creative Storytelling. Routledge, 1995.

6. McGrath, D. \& Macdermott, F. Screencraft: Screenwriting Rotovision, 2003.

7. Benjamin, W. Illuminations. London: Harper-Collins. 1992.

8. Luthi, M. Once Upon a Time. Indiana University Press, 1976. 
9. Mamet, D. On Directing. Faber and Faber, 1989.

10. Frank Kafka to Max Brod in Brod, M Franz Kafka Da Capo Press, 1995

11. Mahmood, I. Influence and Importance of Cinema on the Lifestyle of Educated Youth: A study on University Students of Bangladesh. IOSR J Humanits Soc Sci 2013;17(6):77-80.

Retrieved from www.iosrjournals.org

12. Retrieved from http://rarefilm.net/wpcontent/uploads/2017/02/Sagina-Mahato-1971-3.jpg

13. Retrieved from http://livingtips4u.tk/cypaj/hirak-rajar-deshe1980-full-bangla-movie-bin.php

14. Retrieved from http://www.geocities.ws/chotkab/Movie/Uttam1.html

15. Retrieved from https://www.researchgate.net/profile/Ruchi_Agarwal10/public ation/279017811_Changing_Roles_of_Women_in_Indian_Cin ema/links/5642e76e08aeacfd89388f88/Roles-of-Women-inIndian-Cinema.pdf

16. Retrieved from http://livingtips4u.tk/cypaj/hirak-rajar-deshe1980-full-bangla-movie-bin.php

17. Retrieved from http://rarefilm.net/wpcontent/uploads/2017/02/Sagina-Mahato-1971-3.jpg

18. Retrieved from https://www.imdb.com/list/ls008463669/

19. Mahmood I. Influence and Importance of Cinema on the Lifestyle of Educated Youth: A study on University Students of Bangladesh. IOSR J Humanit Soc Sci, 2013;17(6):77-80. Retrieved from www.iosrjournals.org

20. Retrieved from https://www.wikipedia.org/

How to cite this article: Chakraborty A. Reflection of labour issues in bengali cinema in post colonial era. $J$ Manag Res Anal 2019;6(3):154-8. 